\title{
Specifics of the Tax System to Support Tourism before and during the COVID-19 Pandemic: Evidence from South American Countries
}

\author{
Shirley Consuelo Honajzrová Banús ${ }^{1, *}$ \\ ${ }^{1}$ Institute of Hospitality Management in Prague (Vysoká škola hotelová v Praze 8, spol. s.r.o.), \\ Department of Economics, Svídnická 50618100 Prague 8, Czech Republic.
}

\begin{abstract}
Research background: Following the global trends concerning "tourism taxation," South American governments identified and applied policies on taxation to raise revenues or fiscal relaxation measures to support their tourism sectors as strategies to increase its number of tourists, competitiveness, and the attractiveness of its destinations. Due to the COVID-19 threat, several countries have been forced to turn to emergency tax breaks and temporary changes in taxation measures.

Purpose of the article: This research aims to determine which taxes, fees, and charges that affect the tourism sector in South American countries have been reduced/removed as a short-term measure to support tourism during the COVID-19 crisis.

Methods: The paper is structured from deductive reasoning, which moves from a general to a more specific analysis. First, a basic description of the tax system's specifications that affect South America's tourism sector is presented based on comparative information in the form of an inventory of tourism-related taxes, based on an analytical study. With data obtained from the United Nations World Tourism Organization (UNWTO) and other international organizations which are tracking the policies' responses to COVID-19, an assessment of the key policy responses from these countries related to "tourism taxation" will be made and compared with other regions. Findings \& Value added: The contribution presented focuses on exploring and describing the role of taxes used as a measure to support the tourism sector. Then, the tax incentives/reduction or removal made as a government response to the coronavirus pandemic threat and its possible impacts were analyzed. It also highlights recent trends and interesting practices in South America.
\end{abstract}

Keywords: tax system; tourism; VAT

JEL Classification: $F 68 ; H 71 ; L 83 ; Z 32 ; Z 38$

* Corresponding author: honajzrova@vsh.cz 


\section{Introduction}

For the countries of South America, tourism has the potential to be an engine of socioeconomic development. However, the coronavirus (COVID-19) global pandemic has brought significant impacts in terms of tourism, not only in this sub-region of Latin America but also globally. According to the COVID-19 report of the Economic Commission for Latin America and the Caribbean (ECLAC), tourism from Latin America in 2019 represented 10\% of total exports (goods and services) in the tourism economy in terms of total GDP and employment. "The implication is that developing countries share some common features that retard their ability to extract more benefits from the tourist industry." [1] Along with this, in line with Gnangnon's research [2], "findings call for governments notably in developing countries to develop the tourism sector and concurrently strengthen tax administrations (and possibly design appropriate tax policy for the tourism sector) to derive the full advantage in terms of public revenue from the rise in international tourism receipts."

Between 2016 and early 2020, international tourist arrivals grew at around 10\% per year in Mexico and the three subregions (Caribbean, Central America, South America). In some South American countries such as Argentina, Brazil, Chile, and Peru, the tourism sector depends on national visitors, representing a proportion more significant than $50 \%$. However, as the pandemic reached the region and an increasing number of countries closed their borders in March, these arrivals declined by more than 50\% in March and close to $100 \%$ in April in all three subregions and Mexico. [3] This caused international and national flights to decrease to almost zero.

The countries of Latin America most affected will be those whose gross domestic product has a greater dependence on tourist activities; in this context, the United Nations Conference on Trade and Development (UNCTAD) [4] has the worst forecasts for the Dominican Republic, Ecuador, Mexico, Colombia, and Argentina.

On the other hand, before the pandemic, taxes, fees, or charges have been applied to tourists by the countries in South America, following the global trend. Its purpose was to obtain income from tourism to develop further and promote tourism or, as is typical, to improve the quality of life by funding services for local citizens. [5] According to (Barna, Zsófia) [6], "The tourism tax is one of the most disputed tax forms in Hungary. There is no agreement on the goals of this tax - even within professional circles. The question is if it should serve as a base for tourism development or it should be only a part of the whole budget of local governments."

In 2014 the Organization for Economic Cooperation and Development (OECD) published a study called "Taxation and tourism" [7] on the role of tourism taxes and their impact on destinations' competitiveness and attractiveness. This study was conducted based on a diagnosis (surveys) of its member countries and partner countries. This comparative information in the form of an inventory of tourism-related taxes focused on indirect taxes, fees, and charges in the general categories of 1) arrival and departure; 2) air travel; 3) hotel and accommodation; 4) reduced rates of consumption tax; 5) environment; and 6) incentives. This type of comparative information is not readily available in other subregions, such as South America. [8]

If we look at other regions such as Europe, the Covid-19 outbreak was a hard blow for tourism, and this is how the "Marshall Plan" emerged to save the tourism sector. Thanks to the decrease in sick cases in the summer of 2020, the tourism industry generated income, unlike those obtained in previous years. In conclusion, European countries have shown an active effort to save their tourist economy. If we focus on the tax policy applied to tourism, some countries decided to suspend these taxes temporarily; for example, in Hungary, tax relief was applied: the tourist tax based on guest nights ( $4 \%$ of the room rate) is suspended between Apr 22 and Dec 31, 2020, but municipalities receive budget support from the state 
up to the amount of missing tax. [9] In Spain, the project was put on standby at the ecological rate for airline tickets, which is part of the government's green plan last December 2019 to penalize harmful practices to the environment. [10]

This research aims to analyze the tax policy reforms related to tourism taken by the different governments of South America during the COVID-19 crisis, and if these affected a change of strategy concerning the taxes applied to the tourist before the pandemic. According to this aim, the following hypotheses are determined:

- $\mathrm{H}_{0}$ : The countries of South America, as a tax policy response during the COVID-19 crisis (March-September 2020), applied for temporary exemptions, reductions, or deferred some of the taxes, fees, and charges identified in the inventory.

- $\mathrm{H}_{\mathrm{A}}$ : The countries of South America, as a tax policy response, exempted, reduced, or deferred other taxes that are not related to those analyzed in the inventory.

As the first phase of this research was created an "Inventory of taxes, fees and charges related to tourism in South America" based on a database compiled by the author of this research on taxes, fees, and charges applied to tourism in the categories of 1) arrival and departure; 2) air travel; 3) hotel and accommodation, information gathered before the pandemic, that is, until 2019. This information was then crossed-checked with the current tax policy responses applied by the governments of this sub-region.

\section{Material and methods}

The research is based on related literature, specialized web portals, relevant websites, and correspondence via email with organizations for up-to-date information on the subject of interest. The methods used in this paper also include analysis and study of documents, both primary and secondary data.

As the first phase of this ongoing research, and using the internet as the primary information medium, a comparative matrix (table 1) called: "Inventory of taxes, fees and charges related to tourism in South America" has been collected and created for having a clearer picture on this issue.

With data obtained from the United Nations World Tourism Organization (UNWTO), World Travel Tourism Council (WTTC), OECD, and other international organizations which are tracking the policies' responses to COVID-19, an assessment of the key policy responses from these countries related to "tourism taxation" will be made and compared with other regions.

\section{Theoretical background}

"Tax policy has important economic consequences, both for the national economy and particular groups within the economy. Tax policies are often designed with the intention of stimulating economic growth - although economists differ drastically about which policies are most effective at fostering growth. Taxes can create incentives promoting desirable behavior and disincentives for unwanted behavior. Taxation provides a means to redistribute economic resources towards those with low incomes or special needs. Taxes provide the revenue needed for critical public services such as social security, health care, national defense, and education." [11]

Usually, governments cut taxes to boost the economy by putting more money into taxpayers' pockets. Most of the time, tax cuts are used to end a recession. It's a popular form of expansionary fiscal policy. Tax cuts are reductions to the amount of taxpayers' money that goes toward government revenue. Tax cuts are changes in the lay that reduce the pay payment 
along with government revenue. [12] Marginal rate cuts lead to increases in real GDP and declines in unemployment. [13]

In this context, government policies on taxation directly impact tourism. Whether taxes are applied directly to a tourist (such as an entry or exit tax, visa fees, accommodation taxes - "room/bed tax," or taxes on car rentals), the industry "tourism businesses and products" (airports and airlines, hotels, accommodation, food and beverages, and gambling facilities), or indirectly (such as VAT or sales taxes, which can discourage shopping and benefit countries with lower taxes). These sales taxes may even encourage day trips across borders to shop in areas where taxes are lower. [14] Introducing fiscal relaxation in tourism brings contributions to this sector's development, which may compensate the budget deficit through revenue increases brought on by increasing the tourists' flows. [15] UNWTO has identified 40 different types of these particular tourism taxes. [16]

"Results from estimations with the synthetic control method show that the introduction of a visitor tax leads to a decline in domestic tourism demand. In contrast, there is no effect on international tourism inflows." The research applied in Italian municipalities. [17]

In many countries, the introduction of entry or exit taxes specifically related to air travel is a relatively recent phenomenon, mainly reflecting the increased affordability and growth of international air travel over the past 20 years, particularly since the beginning of the century. This growth, in turn, has led to increased costs to provide the necessary infrastructure, security, and passenger services, and a growing concern about the implications of this growth for the environment since a carbon tax policy could have a remarkable impact on tourism-related carbon emissions and economic welfare [18]. In response, countries have introduced a variety of taxes, fees, and charges to contribute to increasing the cost of providing the service and, in some cases, in an attempt to encourage more environmentally friendly behavior. [7]

The study made by the authors' Song, Seetaram, and Ye [19] examined air passenger duty (APD) on outbound UK tourists' budget allocations. Results demonstrate that the APD modifies UK outbound tourists' budget allocations by increasing the relative share of transportation expenditure while decreasing the at-destination expenditures on items such as accommodation and food.

In its annual publication of "Tax Policy Reforms," the OECD [20] includes a Special Feature that takes stock of the tax and broader fiscal measures introduced by countries in response to the crisis from the beginning of the virus outbreak up to mid-June 2020. According to this data collection, the OECD charted the response phases of the governments' tax policy:

1. Liquidity \& income support

2. Liquidity, solvency \& income support

3. Fiscal stimulus

4. Revenue

\section{Results}

Based on the crossing-checking of information between the inventory of taxes, fees, and charges related to tourism in South America - before the pandemic and the fiscal policy measures to support the Covid-19 crisis of travel tourism, the following results were identified:

\subsection{Air travel - Boarding fees (Entry/exit tax)}

According to the analysis, it was found that some South American countries have explicitly decided to apply a tourism tax to obtain extra income for the development of tourist activity. 
However, some cases are only theoretical since the income can be used to benefit or support other sectors of the economy. According to table 1, the following countries have clearly defined this type of tax:

- Argentina - "Fondo Nacional de Turismo" (National Tourism Fund) applied as an exit tax.

- Bolivia - Contribución Especial para el Fomento, Promoción y Facilitación del Turismo (Special Contribution for the Promotion, Promotion, and Facilitation of Tourism) "Cetur" Law applied since 2017 by air and 2019 by land as an entry tax for tourists entering Bolivian territory.

- Brazil - "Impuesto sobre el turismo" (Tourism tax), applied as an exit tax. "Tasa de preservación ambiental" (Environmental preservation fee) for entering protected areas such as islands.

- Colombia - "Impuesto destinado al turismo" (Tax destined to tourism), applied as an entry tax.

- Ecuador - "Potencia Turística" (Tourist Power) applied as an entry tax and "Eco Delta$E D^{\prime \prime}$ as an exit tax.

- Paraguay - "Turismo" (Tourism) applied as an exit tax.

A growing trend can be highlighted in applying this type of tax by the governments of South America.

The following countries have been identified as having applied fiscal measures to relieve the tax burden to their air transport industry:

- Argentina - The payment of corporate contributions to tourism, passenger transport will be exempted. (20.4\% for the services and commerce sector, as long as its total sales do not exceed the categorization limits as a medium-sized company).

- Brazil - The government also designed an airline relief package - i) a 6-month postponement of the collection of air navigation tariffs; - ii) postponement to December 2020 of the collection of concession fees from airport concessionaires.

- Colombia - VAT exemption until Dec 31, 2020, extended for companies dedicated to commercial passenger air transport. Postponement of the fiscal Contribution payment for the Promotion of Tourism of the first quarter of 2020 until Dec 31, 2020. Rental fees for commercial spaces located at the airports and aerodromes administered by the Civil Aeronautics should be suspended for the emergency period. Charges applied to airport infrastructure should be suspended for the same period. Lower import tariffs were used for inputs used in passenger and freight air transport services. From the second quarter to the third one for 2020, the extension of payment deadlines of the corporate income taxes (CIT) for taxpayer's commercial passenger air transport services. The advance payment for the 2020 income tax return will be the $0 \%$ rate applies to businesses engaged in transportation.

- Ecuador - Six months VAT payment deferral of the income tax for airlines.

\subsection{Hotel and accommodation}

This section refers to specific taxes for hotels and other lodging facilities, such as taxes per room "tax room," overnight "bed night taxes," and occupancy taxes "occupancy taxes."

The first results indicated that Argentina, Brazil, and Ecuador use this type of tax, mainly in the most visited cities and places where they want to obtain income to protect nature and infrastructure. The municipal governments of Peru and Uruguay have it as a project.

The following countries have been identified as having applied fiscal measures to support this sector specifically:

- Argentina - Temporarily exempt from the payment of employer contributions to the sectors critically affected by this pandemic, tourism, food, and accommodation. 
- The payment of corporate contributions to tourism, hotel companies will be exempted. (20.4\% for the services and commerce sector, as long as its total sales do not exceed the categorization limits as a medium-sized company).

- Colombia - The payment dates for the following taxes were postponed: the income tax and complementary for the 2019 taxable year; the VAT for those that have as an economic activity food and beverage dispensing services, bars, hotels, travel agencies, airlines, and tour operators, national consumption tax for the two months March-April 2020 for those responsible of food and beverage services; parafiscal Contribution for the Promotion of Tourism of the first quarter of 2020.

- Ecuador-Six months IVA payment deferral from April to June and 2019 income tax for accommodation and food businesses.

- Peru - The Ministry of Foreign Trade and Tourism (MINCETUR), through the Peruvian Export Promotion Commission and the Tourism (PROMPERÚ), exempt companies related to the export and tourism sector from the payment of fees when it comes to participating in national and international promotion platforms carried out during this 2020.

It is essential to mention that "in recent years, what has become known as collaborative consumption has undergone rapid expansion through peer-to-peer (P2P) platforms. In the field of tourism, a particularly notable example is that of Airbnb." [21] Although this research does not include the analysis of Airbnb behavior in South America, it could be interesting to know more about taxation in this type of accommodation service.

\subsection{VAT exemption "TAX FREE" - VAT refund}

The value-added tax "VAT" is applied to transactions; however, it is a final consumption tax credited against the merchant sales tax. Although VAT generally has a standard rate (\%) for most goods and services, in practice, it is theoretically feasible and customary to implement different rates in some sectors (e.g., tourism-related goods and services). [7]

The South American governments use as a strategy the exemption of VAT or its refund in tourist accommodation to promote and encourage exports since inbound tourism contributes to the service exports. Together with this, some countries eliminate the tax on purchases as a measure that also attracts more tourists, especially targeting neighboring countries interested in shopping. "Given the tourism sector importance, the purchases were considered by UNWTO as the segment with the highest potential growth." [22] One of the main benefits of the tax-free shopping (TFS) program is that it allows the state to collect necessary information on international visitors. [23]

Research results found that the most active countries concerning this type of exemption or refund in tourist accommodation and purchases are Uruguay, Argentina, Colombia, Ecuador, and Peru. Uruguay's Ministry of Tourism official web page offers other additional benefits (temporary incentive for tourists), including a 22\% VAT refund on gastronomic services, catering, parties and events, vehicle, and real estate rental.

Likewise, according to the information collected, Argentina and Uruguay use the company Global Blue SA for the VAT refund process, which has modernized and streamlined the refund process.

With this type of incentive, which is applied directly as a benefit to tourists, no information has been found that the governments of South America during the pandemic have decided to remove this type of benefit. On the other hand, VAT has been used as relief for companies related to tourism, which applies Chile's case (postponement of VAT payment), and Colombia's case (VAT exemption). Six months VAT payment deferral applies in Ecuador. Deferral of VAT as stipulated for the CIT in Peru and Uruguay. 
After identifying the three types of tourism taxes that the governments of South America have implemented before the COVID-19 crisis, and the tax policy measures to support tourism during the pandemic, a zero hypothesis is rejected $\left(\mathrm{H}_{0}\right.$ : The countries of South America, as a tax policy response during the COVID-19 crisis (March-September 2020), applied for temporary exemptions, reductions, or deferred some of the taxes, fees, and charges identified in the inventory). An alternative hypothesis is accepted $\left(\mathrm{H}_{\mathrm{A}}\right.$ : The countries of South America, as a tax policy response, exempted, reduced, or deferred other taxes that are not related to those analyzed in the inventory).

\section{Discussions and conclusions}

Based on the information collected in South America and following the global trend of raising monetary resources to promote tourism, it has been identified that the central taxes and fees that affect or benefit tourists are the boarding fees at airports, the tourist tax applied to lodgings, and the TAX-FREE or VAT refund in accommodation and shopping. The number of taxes applied to tourism tends to increase in this Latin American subregion; for example, Argentina's government had just launched a "pernocte tax" on accommodation and cruises in the city of Buenos Aires from the 1st. March of this year. [24]

When the South American countries were in late summer and vacation time, they were struck by the pandemic. These countries have responded with different fiscal measures during the fall and winter according to their governments' economy. Among the general measures applied by these governments, the vast majority have responded as summarized by the OECD (liquidity \& income support; liquidity, solvency \& income support; fiscal stimulus and revenue).

Included in the main tax policy reforms applied was the relief of tax burdens companies such as the CIT exemptions or postponement payment, personal income tax (PIT), temporarily exemptions/extensions from the payment of employer contributions, tax liabilities had been deferred for firms, postponement of VAT payment or changes in VAT rates. Within the ten countries analyzed, it has been identified that few have responded with specific fiscal measures to support the industries of their tourism sector, among them: Argentina, Colombia, and Ecuador, countries that are most affected since their gross domestic product are more dependent on tourism activities. [4]

It should be noted that Colombia postponed the fiscal Contribution for the Promotion of Tourism (a tax burden that affected the businesses related to tourism) from the first quarter of 2020 until Dec 31, 2020. Peru applied as other tax policy measures an accelerated or enhanced tax depreciation provisions for travel agencies and tourism or restaurants and related services.

The hypothesis that South American countries would respond with measures modifying some of the taxes applied to tourists has been rejected. However, it is not ruled out that this is not a future strategy that would be applied for the summer and vacation season of this year and that it is soon to arrive; nevertheless, everything will depend on the control in the growth of COVID-19 cases in the subregion and the improvement of the conditions of their health system, which is the sector that needs the most investment for its improvement.

According to Saint-Amans [25], international tax co-operation will be even more necessary to prevent tax disputes from turning into trade wars, which would harm recovery at a time when the global economy can least afford it. 
Table 1: Specifics of the tax system to support tourism before and during the COVID-19 Pandemic

\begin{tabular}{|c|c|c|}
\hline Country & $\begin{array}{c}\text { Inventory: Taxes, fees, and charges related } \\
\text { to tourism in South America - Before the } \\
\text { Covid-19 crisis }\end{array}$ & $\begin{array}{l}\text { COVID-19 policies response measures } \\
\text { targeting tourism: Highlights }\end{array}$ \\
\hline \multirow{3}{*}{ 吾 } & $\begin{array}{l}\text { Air travel - "Fondo Nacional de Turismo" } \\
\text { (National Tourism Fund) }\end{array}$ & \multirow{3}{*}{$\begin{array}{l}\text { Temporarily exempt from the payment of } \\
\text { employer contributions to the sectors critically } \\
\text { affected by this pandemic, among them tourism, } \\
\text { entertainment industries, food, and } \\
\text { accommodation. } \\
\text { The payment of corporate contributions to } \\
\text { tourism, passenger transport, and hotel } \\
\text { companies will be exempted. }\end{array}$} \\
\hline & $\begin{array}{l}\text { Hotel and accommodation - Tourist tax } \\
\text { "Ecotax" Iguazú or Bariloche. Tasa de Pernocte } \\
\text { (LAW 6278) }\end{array}$ & \\
\hline & $\begin{array}{l}\text { VAT exemption "TAX FREE" - VAT refund - } \\
21 \% \text { Tax-free in hotels. }\end{array}$ & \\
\hline \multirow{3}{*}{ 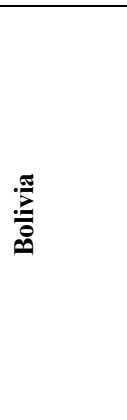 } & $\begin{array}{l}\text { Air travel - Contribución Especial para el } \\
\text { Fomento, Promoción y Facilitación del } \\
\text { Turismo (Special Contribution for the } \\
\text { Promotion, Promotion, and Facilitation of } \\
\text { Tourism) "Cetur" Departure Tax - Tax on Air } \\
\text { Departures Abroad (ISAE) Bs. 348, around 50 } \\
\text { dollars. }\end{array}$ & \multirow{3}{*}{$\begin{array}{l}\text { Resources were injected to increment in } 50 \% \\
\text { the liquidity of the financial intermediation } \\
\text { entities to sustain the internal demand, and } \\
\text { payment of credits was suspended until June. } \\
\text { Source: UNDP } \\
\text { - Granting soft and easy loans to companies to } \\
\text { pay wages for two months and avoid massive } \\
\text { layoffs. Source: UNDP } \\
\text { - Direct support to } 2 \text { million beneficiaries of the } \\
\text { MSMEs support program through the financial } \\
\text { system (US\$ } 200 \text { million). Source: UNDP } \\
\text { 2.7.2020 }\end{array}$} \\
\hline & No occupancy taxes. "TAX FREE" & \\
\hline & $\begin{array}{l}\text { VAT exemption "TAX FREE" - VAT refund - } \\
\text { Sales of tourist services and accommodation for } \\
\text { tourists and foreigners have a } 13 \% \text { VAT } \\
\text { discount. }\end{array}$ & \\
\hline \multirow{3}{*}{ 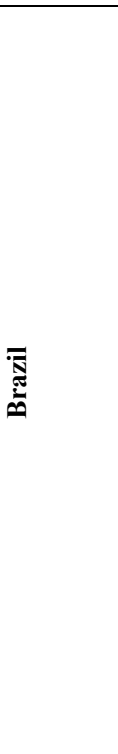 } & $\begin{array}{l}\text { Air travel - The international departure tax } \\
\text { from Brazil is } \mathrm{R} \$ 113 \text {. The domestic departure } \\
\text { tax ranges from } \mathrm{R} \$ 25 \text { to } \mathrm{R} \$ 40 \text {. These fees are } \\
\text { always included in the ticket price. "Impuesto } \\
\text { sobre el turismo" and "Tasa de preservación } \\
\text { Ambiental," to enter protected areas such as } \\
\text { islands. }\end{array}$ & \multirow{3}{*}{$\begin{array}{l}\text { The Ministry of Economy announced a package } \\
\text { of R\$ } 147.3 \text { billion to help the economy against } \\
\text { the effects of the disease. } \\
\text { According to OECD, the following measures } \\
\text { have been adopted: } \\
\text { - Tax liabilities have been deferred for firms, } \\
\text { especially SMEs. } \\
\text { - The government also designed an airlines } \\
\text { relief package, including: } \\
\text { - i) a } 6 \text {-month postponement of the collection } \\
\text { of air navigation tariffs; } \\
\text { - ii) postponement to December } 2020 \text { of the } \\
\text { collection of concession fees from airport } \\
\text { concessionaires; and } \\
\text { - iii) a } 12-\text {-month extension period for } \\
\text { companies to reimburse customers for canceled } \\
\text { flights. } 23.4 .2020\end{array}$} \\
\hline & $\begin{array}{l}\text { Hotel and accommodation - Depending on the } \\
\text { city, the Tax on Services (ISS) can range } \\
\text { between } 2 \% \text { and } 5 \% \text {. Specifically related to } \\
\text { hotel services, "ISS" is added to the value of the } \\
\text { daily rate. } \\
\text { The tourism fee was established by the } \\
\text { Department of Tourism of each municipality. } \\
\text { (optional) } \\
\text { Doação por Tourism (DPT) can be added to the } \\
\text { daily hotel rates in Brazil. The DPT is only } \\
\text { collected in some cities and is also an optional } \\
\text { contribution collected by hotels that are } \\
\text { members of the Office of Convention and } \\
\text { Visitors Associations. }\end{array}$ & \\
\hline & $\begin{array}{l}\text { VAT exemption "TAX FREE" - VAT refund - No } \\
\text { tax-free neither VAT refund. }\end{array}$ & \\
\hline \multirow[b]{3}{*}{ 坣 } & $\begin{array}{l}\text { Air travel - Exit tax US \$ } 9 \text { domestic flights. } \\
\text { The rate for international flights will decrease } \\
\text { to } \$ 25 \text { in } 2019 .(02 / 15 / 2019)\end{array}$ & \multirow{3}{*}{$\begin{array}{l}\text { - Postponement of VAT payment. } \\
\text { - Postponement until July } 2020 \text { of the payment } \\
\text { of income tax for SMEs according to what they } \\
\text { declare in the income operation of next April. } \\
\text { - Temporary cut on stamp duty to } 0 \% \text { for all } \\
\text { credit operations during the next six months. } \\
\text { - Relief measures for the treatment of tax debts } \\
\text { with the General Treasury of the Republic } \\
\text { focused on SMEs and people with lower } \\
\text { incomes. } \\
\text { - All the expenses of the companies associated } \\
\text { with facing the health contingency will be } \\
\text { accepted as a tax expense. } \\
\end{array}$} \\
\hline & Hotel and accommodation - No occupancy tax. & \\
\hline & $\begin{array}{l}\text { VAT exemption "TAX FREE" - VAT } \\
\text { refund- } 19 \% \text { discount for foreign tourists. In } \\
\text { some cases, the stated tax is added to meals and } \\
\text { even tours of an all-inclusive destination } \\
\text { package. }\end{array}$ & \\
\hline & $\begin{array}{l}\text { Air travel - Entry tax - Tourism tax }(\$ 15 \text { per } \\
\text { person is charged by the airlines to all foreign }\end{array}$ & $\begin{array}{c}\text { VAT exemption until Dec } 31,2020 \text {, } \\
\text { extended for companies dedicated to }\end{array}$ \\
\hline
\end{tabular}




\begin{tabular}{|c|c|c|}
\hline & $\begin{array}{l}\text { travelers who enter the country on an } \\
\text { international route. Exit tax - Exit tax (stamp) } \\
\text { about } \$ 38 \text { or } \$ 68,000 \text { (Airport Tax) }\end{array}$ & $\begin{array}{l}\text { commercial passenger air transport, the hotel } \\
\text { sector, among others that may be affected by the } \\
\text { situation of the COVID-19; }\end{array}$ \\
\hline & Hotel and accommodation - No occupancy tax. & - Postponement of the payment of the fiscal \\
\hline & $\begin{array}{l}\text { VAT exemption "TAX FREE" - VAT refund- For } \\
\text { accommodation and shopping }(19 \%) \text {. }\end{array}$ & $\begin{array}{l}\text { Contribution for the Promotion of Tourism } \\
\text { of the first quarter of } \mathbf{2 0 2 0} \text { until Dec } \mathbf{3 1 , 2 0 2 0} \text {; } \\
\cdot \text { Rental fees for commercial spaces located at } \\
\text { the airports and aerodromes administered by the } \\
\text { Civil Aeronautics should be suspended for the } \\
\text { emergency period; charges applied to airport } \\
\text { infrastructure should be suspended for the same } \\
\text { period. }\end{array}$ \\
\hline & $\begin{array}{l}\text { Air travel - "Potencia Turística" (Tourist } \\
\text { Power) applied as an entry tax and "Eco Delta- } \\
E D " \text { as an exit tax. }\end{array}$ & $\begin{array}{l}\text { The government is considering postponing the } \\
\text { collection of quotas for up to } 60 \text { days, of } \\
\text { personal credits, of microcredit, and those }\end{array}$ \\
\hline 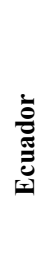 & $\begin{array}{l}\text { Hotel and accommodation - "Fee for Tourist } \\
\text { Facilities and Services" in the city of Quito. In } \\
\text { Guayaquil, they must consider in their budget } \\
\text { the payment of between USD } 1 \text { and } 2 \text { additional } \\
\text { when they cancel the item for accommodation } \\
\text { in hotels in the city and the Main Port the } \\
\text { payment of an overnight fee in Luxury and First } \\
\text { Category hotels. }\end{array}$ & $\begin{array}{l}\text { granted to small companies, deferring them } \\
\text { without surcharge. } \\
\text { Six months IVA payment deferral from April } \\
\text { to June as well as } 2019 \text { income tax for small } \\
\text { companies, airlines, accommodation, and food } \\
\text { businesses. } \\
\text { A presidential decree which enables tax } \\
\text { deferral, Ordinance No. } 1021\end{array}$ \\
\hline & $\begin{array}{l}\text { VAT exemption "TAX FREE" - VAT refund- } \\
\text { Foreign tourists have the right to refund the } \\
\text { VAT paid for the hiring of tourist } \\
\text { accommodation services and goods acquisition. }\end{array}$ & $\begin{array}{l}\text { MINTUR requests the Ministry of Finance } \\
\text { and Economy to expand tax deferral to the } \\
\text { tourism sector. } \quad 29.5 .2020\end{array}$ \\
\hline & $\begin{array}{l}\text { Air travel - Exit tax, the international boarding } \\
\text { fee is } 40 \text { dollars ( } 28 \text { dollars for the National } \\
\text { Directorate of Civil Aeronautics "DINAC" and } \\
12 \text { dollars TOURISM) }\end{array}$ & $\begin{array}{l}\text { Among the measures requested: } \\
\text { - reduction of the payment of the VAT (the } \\
\text { government has already approved this measure } \\
\text { and } 5 \% \text { will be paid instead of } 10 \% \text { ), }\end{array}$ \\
\hline$\vec{E}$ & Hotel and accommodation - No occupancy tax. & - the flexibility of labor contracts, and the \\
\hline 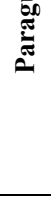 & $\begin{array}{l}\text { VAT exemption "TAX FREE" - VAT refund - } \\
\text { There is a project to return the VAT to the } \\
\text { tourist. } \\
\text { Regime of tourism: a tax settlement regime that } \\
\text { levies the import of goods sold in the country } \\
\text { exclusively to non-domiciled individuals. }\end{array}$ & $\begin{array}{l}\text { reduction of the employer-worker contribution, } \\
\text { - exemption for one year of } 50 \% \text { in the bills for } \\
\text { public services of ANDE, ESSAP, and } \\
\text { COPACO, } \\
\text { - the elimination of the advance on business } \\
\text { income. }\end{array}$ \\
\hline & $\begin{array}{l}\text { Air travel - Exit tax to leave the country of } \$ \\
30 \text {. There is also a } \$ 6 \text { tax for domestic flights. }\end{array}$ & $\begin{array}{l}\text { The Ministry of Foreign Trade and Tourism } \\
\text { (MINCETUR), through the Peruvian Export }\end{array}$ \\
\hline E & $\begin{array}{l}\text { Hotel and accommodation - Project in Lima for } \\
\text { a new "tax room" overnight charge contributes } \\
\text { to the destination's promotion, with the hotels } \\
\text { being the fund-raising entities that will then go } \\
\text { to a trust administered jointly by the } \\
\text { Metropolitan Municipality and the private } \\
\text { sector. }\end{array}$ & $\begin{array}{l}\text { Promotion Commission and the Tourism } \\
\text { (PROMPERÚ), exempt companies related to } \\
\text { the export and tourism sector from the payment } \\
\text { of fees when it comes to participating in } \\
\text { national and international promotion platforms } \\
\text { carried out during this } 2020.2 .7 .2020 \\
\text { Deferral of VAT as stipulated for the CIT. }\end{array}$ \\
\hline & $\begin{array}{l}\text { VAT exemption "TAX FREE" - VAT refund - } \\
\text { Since 11.23.2017, the Benefit for Lodging } \\
\text { Establishments that provide services to Non- } \\
\text { Resident Persons has been in force. Supreme } \\
\text { Decree No. } 342-2017-E F \text {. A new regime (2017) } \\
\text { was established to reimburse tourists for VAT } \\
\text { paid in Peru to acquire certain goods. }\end{array}$ & $\begin{array}{l}\text { Travel agencies and tourism or restaurants and } \\
\text { related services are able to depreciate their } \\
\text { building and constructions at a rate of } 20 \% \text { in } \\
2021 \text { and } 2022 \text { if it has a value to depreciate as } \\
\text { of } 31 \text { December 2020. Taxpayers may } \\
\text { depreciate at a } 33.3 \% \text { rate if the fixed assets are } \\
\text { ground transportation vehicles (except } \\
\text { railways). }\end{array}$ \\
\hline & $\begin{array}{l}\text { Air travel - Exit tax, on international flights, an } \\
\text { additional tax of } \$ 46.00 \text { is applied, which has } \\
\text { an additional fee of } \$ 5.76 \text { for security. } \\
\text { (Carrasco Airport, in Montevideo) }\end{array}$ & $\begin{array}{l}\text { Loans for SMEs, subsidies, extension of tax } \\
\text { contributions, investment. } \\
\text { http://www.pulsoturistico.com.ar/ }\end{array}$ \\
\hline 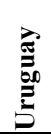 & $\begin{array}{l}\text { Hotel and accommodation - The Municipality } \\
\text { of Montevideo (IMM) included in its } 2019 \\
\text { budget modification message a fee to charge } \\
\text { tourists each night they stay in the capital. }\end{array}$ & \\
\hline
\end{tabular}




\begin{tabular}{|c|c|c|}
\hline & $\begin{array}{l}\text { VAT exemption "TAX FREE" - VAT refund - } \\
\text { Zero VAT in Hotels. The tax-Free regime for } \\
\text { product purchases. (Transitory incentive) }\end{array}$ & \\
\hline \multirow{3}{*}{ 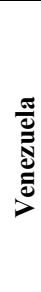 } & $\begin{array}{l}\text { Air travel - Exit tax, the departure airport fee, } \\
\text { equivalent to } 30 \text { dollars, will be applied to } \\
\text { foreign citizens who are not Venezuela } \\
\text { residents according to resolution No. } 066 \\
\text { published in Official Gazette } 41223 \text { of August } \\
28,2017 \text {. }\end{array}$ & \multirow[t]{3}{*}{$\begin{array}{l}\text { No available information, but the private sector } \\
\text { was requesting government support for the } \\
\text { tourism sector. }\end{array}$} \\
\hline & Hotel and accommodation - No occupancy tax. & \\
\hline & $\begin{array}{l}\text { VAT exemption "TAX FREE" - VAT refund - No } \\
\text { VAT exemption. }\end{array}$ & \\
\hline
\end{tabular}

Source: Own research based on data compiled on official websites of each country. (Ministries of Tourism, Government Ministries, Airports, UNWTO, WTTC, OECD, etc.). It is updated to this date: September 2020.

\section{References}

1. Singh, D.H.R. (2010). Tourism income multipliers for Latin American countries. Tourism Analysis Journal, 15(4), 485-488.

2. Gnangnon, S.K. (2020). Impact of international tourism receipts on public revenue in developed and developing countries. Tourism Review, Early Access.

3. Economic Commission for Latin America and the Caribbean (ECLAC). (2020, July). Recovery measures for the tourism sector in Latin America and the Caribbean present an opportunity to promote sustainability and resilience. Retrieved from: https://repositorio.cepal.org/bitstream/handle/11362/45767/4/S2000440_en.pdf

4. United Nations Conference on Trade and Development (UNCTAD). (2020, July) Covid19 and Tourism: Assessing the Economic Consequences. Retrieved from: https://unctad.org/en/PublicationsLibrary/ditcinf2020d3_en.pdf

5. Honajzrová Banús, C., Petříček, M. (2019). Specifics of the Tax System to Support Tourism: Evidence from Argentina and Uruguay. In Khalid S. Soliman (Ed.). Proceedings of the 33rd International Business Information Management Association Conference (pp. 1198-1208). Granada: Spain.

6. Barna Katalin, M., Zsófia, P. (2017). Analysis of the tourism tax between 2000 and 2013 in Hungary. Teruleti Statisztika, 57(2), 224-243.

7. OECD Tourism Trends and Policies (2014, 2016, 2018). Edition. Retrieved from: https://www.oecd-ilibrary.org/industry-and-services/oecd-tourism-trends-and-policies2014_tour-2014-en

8. Honajzrová Banús, C. (2019). Inventario de impuestos, tasas y cargos relacionados con el turismo en Sud América y su impacto en el número de llegadas de turistas. In Khalid S. Soliman (Ed.). Proceedings of the 34th International Business Information Management Association Conference (p. 205 - 214, 10 pp.). Madrid: Spain.

9. OECD Policy Responses to Coronavirus (COVID-19). (Updated 2020, June). Tackling coronavirus (COVID-19) Contributing to a global effort. Retrieved from: https://www.oecd.org/coronavirus/policy-responses/tourism-policy-responses-to-thecoronavirus-covid-19-6466aa20/\#section-d1e4199

10. Tourinews. (2020). España paraliza la tasa ecológica a los billetes de avión. Retrieved from: https://www.tourinews.es/ 
11. Roach, B. (2010). Taxes in the United States: History, Fairness, and Current Political Issues. Tufts University Global Development and Environment Institute. Retrieved from: http://www.bu.edu/eci/files/2019/06/Taxes_in_the_United_States.pdf

12. TurboTax. (Accessed July 18, 2020). "What Are Tax Cuts?" Retrieved from:https://turbotax.intuit.com/tax-tips/general/what-are-tax-cuts/L1wXFN8CF

13. Mertens, K., Olea, J.L.M. (2018). Marginal Tax Rates and Income: new time series evidence. Quarterly Journal of Economics, 133(4), 1803-1884.

14. Holloway, J.CH. (2009). The Business of Tourism, 8th Edition, England.

15. Paula, S., Mariana, B. (2016). Effects of Value Added Tax (VAT) reduction on tourism in Romania. In K.S. Soliman (Ed.). Proceedings of the 27th International Business Information Management Association Conference (pp. 829-836). Milan: Italy.

16. Gooroochurn, N., Sinclair, T. (2005) Economics of tourism taxation: evidence from Mauritius, Annals of Tourism Research, 32(2), 478-498.

17. Biagi, B., Brandano, M.G., Pulina, M. (2017). Tourism taxation: A synthetic control method for policy evaluation. International Journal of Tourism Research, 19(5), 505514.

18. Zhang, J.K., Zhang, Y. (2018). Carbon tax, tourism CO2 emissions, and economic welfare. Annals of Tourism Research, 69, 18-30.

19. Song, H., Seetaram, N., Ye, S. (2019). The effect of tourism taxation on tourists' budget allocation. Journal of Destination Marketing and Management, 11, 32-39.

20. OECD and Selected Partner Economies. (2020, September) Tax Policy Reforms 2020. Retrieved from: https://www.oecd.org/tax/tax-policy-reforms-26173433.htm

21. Gutierrez, J., Garcia-Palomares, J.C., Romanillos, G., Salas-Olmedo, M.H. (2017). The eruption of Airbnb in tourist cities: Comparing spatial patterns of hotels and peer-to-peer accommodation in Barcelona. Tourism Management, 62, 278-291.

22. Liberato, D., Silva, M., Liberato, P. (2018). Shopping tourism: City of Lisbon as a shopping destination. In K.S. Soliman (Ed.). Proceedings of the 32nd International Business Information Management Association Conference (pp. 5002-5013). Seville: Spain

23. Dimanche, F. (2003) The Louisiana Tax-Free Shopping Program for International Visitors: A Case Study. Journal of Travel Research, 41(3), 311-314.

24. Law, 6278 (2020). Retrieved from: http://www2.cedom.gob.ar/es/legislacion/normas/ leyes/ley6278.html

25. Saint-Amans, P. (2020, September). Supporting the global economy: what role for tax systems in responding to COVID-19? OECD publication. Retrieved from: https://www.oecd-forum.org/posts/supporting-the-global-economy-what-role-for-taxsystems-in-responding-to-covid-19?utm_source=Adestra\&utm_medium=email\&utm content $=$ Read $\% 20$ the $\% 20$ blog\%20post\&utm_campaign $=$ Tax $\% 20$ News $\% 20$ Alert $\% 20 \overline{1}$ 0-09-2020\&utm_term=ctp 